\title{
Yumurtacı Tavuk Diyetine Ayçiçek Yağı ve Selenyum ilavesinin Performans, Yumurta Kalitesi ve Yumurta Raf Ömrü Üzerine Etkileri*
}

\author{
Çağrı KALE ${ }^{1 a \bowtie}$, Nuriye Tuğba BiNGÖ ${ }^{2 b}$
}

1. Van Yüzüncü Yıl Üniversitesi, Veteriner Fakültesi, Hayvan Besleme ve Belenme Hastalıkları Anabilim Dalı, Van, TÜRKiYE. ORCID: 0000-0003-1918-6346a, 0000-0002-6894-8418

\begin{tabular}{|c|c|c|}
\hline $\begin{array}{c}\text { Geliş Tarihi/Received } \\
22.05 .2021 \\
\end{array}$ & $\begin{array}{c}\text { Kabul Tarihi/Accepted } \\
19.08 .2021 \\
\end{array}$ & $\begin{array}{c}\text { Yayın Tarihi/Published } \\
30.12 .2021 \\
\end{array}$ \\
\hline \multicolumn{3}{|c|}{$\begin{array}{l}\text { Bu makaleye atıfta bulunmak için/To cite this article: } \\
\text { Kale Ç, Bingöl NT: Yumurtacı Tavuk Diyetine Ayçiçek Yağı ve Selenyum İlavesinin Performans, Yumurta Kalitesi ve Yumurta } \\
\text { Raf Ömrü Üzerine Etkileri. Atatürk Üniversitesi Vet. Bil. Derg., 16(3): 259-268, 2021. DOI: 10.17094/ataunivbd.940934 }\end{array}$} \\
\hline $\begin{array}{l}\text { Öz: Bu denemede; yumurtacı ta } \\
\text { bakımından zenginleştirilmiş m } \\
\text { Toplam } 252 \text { adet } 42 \text { haftalık y } \\
\text { rastgele dağıtıldı. Deneme dese } \\
\text { Ayçiçek yağlı (\%3) ve yağsız ola } \\
\text { diyeti oluşturuldu. Deneme } 1 \\
\text { yararlanma oranı, özgül ağırlık, } \\
\text { yumurta ağırlığı, şekil indeksi, ka } \\
\text { ( } P<0.05) \text {. Yumurta sarısı tiyoba } \\
\text { yüksek ( } P<0.05 \text { ) tespit edildi. } \\
(P<0.05) \text {. Sonuç olarak; yumur }\end{array}$ & $\begin{array}{l}\text { k yağı ve/veya inorgar } \\
\text { rformans, yumurta ka } \\
\text { z yumurtacı tavuk, } 7 \\
\text { sellerine göre dizayn } \\
\text { iki ayrı diyete, iki fark } \\
\text { Denemede, gruplar } \\
\text { sarı oranı bakımındaı } \\
\text { lınlığı, yumurta sarı re } \\
\text { leri (TBARS) sadece ay } \\
\text { yağlı diyetle beslen } \\
\text { ayçiçek yağı ve/veya }\end{array}$ & $\begin{array}{l}\text { (0.3 mg/kg) yapılarak } 6 \text { denem } \\
\text { verimi, yem tüketimi, yemde } \\
\text { nemli bir farklılık gözlenmezke } \\
\text { inde önemli farklılıklar belirlen } \\
\text { upta diğer gruplara kıyasla dar } \\
5 \text { değerini düşürdüğü belirlen }\end{array}$ \\
\hline
\end{tabular}

Anahtar Kelimeler: Ayçiçek yağı, Performans, Raf ömrü, Selenyum, Yumurta kalitesi.

\section{The Effects of Sunflower Oil and Selenium Supplementation to Laying Hen Diet on Performance, Egg Quality and Egg Shelf Life}

\begin{abstract}
In this experiment; the effects of additions sunflower oil and/or inorganic (sodium selenite) and organic selenium (selenium-enriched yeast) to laying hen diet on performance, egg quality and egg shelf life were investigated. A total of 252 42-week-old Lohmann LSL white laying hens were randomly assigned to 6 experimental groups with 7 replications ( 6 chickens per repeat). Experimental pattern was created according to a factorial experiment plan designed according to $2 \times 3$ random plots. Six experiment diets were created by adding two different selenium $(0.3 \mathrm{mg} / \mathrm{kg})$ to both diets prepared with/without sunflower oil (3\%). The experiment was continued for 12 weeks. Although no significant difference was observed between the groups in terms of egg production, feed consumption, feed conversion ratio, specific gravity, Haugh unit, albumen and yolk ratio in the experiment, significant differences were determined in egg weight, shape index, shell ratio, shell thickness, egg yolk color, albumen and yolk ratio $(P<0.05)$. Egg yolk thiobarbituric acid reactive substances (TBARS) were higher $(P<0.05)$ in group added only sunflower oil compared to other experimental groups. It was determined that selenium supplementation decreased TBARS value in groups fed a fatty diet $(\mathrm{P}<0.05)$. As a result; It was observed that the addition of sunflower oil and/or different sources of selenium to the laying hen diet did not affect performance and egg quality parameters in general; the addition of sunflower oil to the diet increased the egg yolk TBARS value, selenium supplementation prevented this increase and had favorable effects on egg shelf life.
\end{abstract}

Keywords: Egg quality, Performance, Selenium, Shelf life, Sunflower oil.

\footnotetext{
Q Çağrı Kale

Van Yüzüncü Yı Üniversitesi, Veteriner Fakültesi, Hayvan Besleme ve Belenme Hastalıkları Anabilim Dalı, Van, TÜRKiYE. e-posta: cagrikale@yyu.edu.tr

*Bu çalışma, birinci yazarın Doktora tezinden özetlenmiştir. Van Yüzüncü Yıl Üniversitesi, Bilimsel Araştırma Projeleri Koordinasyon Birimi tarafından TDK-2016-5089 nolu proje ile desteklenmiștir.
} 
GiRiş

Vumurta; sahip olduğu protein, aminoasitler, yağ asitleri, vitamin ve mineraller sayesinde en önemli besin kaynaklarının başında gelir. Kaliteli bir hayvansal protein kaynağı olması sebebiyle de tüketimi en fazla olan ürünlerden bir tanesidir. Dolayısıyla; kanatlı sektörü ülkemizde ve dünyada hızla büyüyen bir hayvansal üretim dalı olarak ilerlemektedir (1). Kanatlı diyetlerinde enerji dengesini sağlamak amacıyla yağlar sıklıkla kullanılmaktadır. Ayçiçek yağı, kullanılan bu yağlardan bir tanesidir. Fakat ayçiçek yağı sahip olduğu çoklu doymamış yağ asidi profilinden dolayı, oksidasyona oldukça duyarlıdır (2). Yapısında bulunan linoleik asit, gerek ayçiçek yağının kullanıldığı diyetlerin, gerekse de bu diyeti tüketen hayvanlardan elde edilen ürünlerin muhafaza edilmesinde sorun teşkil etmektedir. Bundan dolayı; kanatlı diyetlerinde kullanılan özellikle bitkisel yağların yaratacağı olumsuzlukları engellemek adına diyetlere antioksidan ilavesi tercih edilmektedir. Bu antioksidan maddelerden bir tanesi de selenyumdur. Selenyum; başta antioksidan bir enzim olan GSH-Px olmak üzere birçok enzimin yapısına dahil olarak antioksidan savunma sisteminde önemli rol oynamaktadır (1). Farklı türde antioksidan maddeler kanatlı diyetlerinde kullanılmakla birlikte, son yıllarda organik kaynaklı antioksidanlar ilgi görmektedir.

$\mathrm{Bu}$ çalışma, ayçiçek yağlı ve yağsız olarak hazırlanan iki farklı yumurtacı tavuk diyetine ilave edilen inorganik veya organik selenyumun, performans, yumurta kalitesi ve yumurta raf ömrü üzerine etkilerinin tespit edilmesi amacıyla yapıldı.

\section{MATERYAL ve METOT}

\section{Hayvanlar, Diyetler ve Deneme Dizaynı}

Bu deneme Van Yüzüncü Yıl Üniversitesi Hayvan Deneyleri Yerel Etik Kurulu'nun 24.03.2016 tarih, 2016/3 nolu kararı ve denetimi altında, özel bir işletmeden temin edilen 42 haftalık yaşta toplam 252 adet Lohmann LSL-Classic beyaz yumurtacı tavuk ile yapıldı. Tavuklar, her bir muamele grubunda 7 tekrar ve her tekrarda 6 hayvan olacak şekilde 6 deneme grubuna $(6 \times 7 \times 6)$ rastgele dağıtıldı. Deneme deseni; $2 \times 3$ tesadüf parsellerine göre dizayn edilmiş faktöriyel deneme planına göre oluşturuldu. Deneme diyetlerinin hazırlanmasında kullanılan ham maddeler (mısır, buğday, soya fasulyesi küspesi, ayçiçeği küspesi, mısır gluteni, buğday kepeği, dikalsiyum fosfat, DL-metiyonin, kireç taşı ve tuz) ticari bir işletmeden satın alındı. Ayçiçek yağı piyasadan alındı. Diyetlere ilave edilen inorganik selenyum ve organik selenyum kaynakları ile vitamin premiksi ve selenyum içermeyen mineral premiksi özel bir firmadan temin edildi. Mısır ve soya esaslı olmak üzere, ayçiçek yağlı ve yağsız iki ayrı deneme diyeti çalışma ekibi tarafından belirtilen oranlarda karıştırılarak yapıldı. Diyetler izokalorik ve izonitrojenik olarak hazırlandı. Hazırlanan iki ayrı temel diyete $\% 45.658$ oranında selenyum içeren toz formda inorganik selenyum (sodyum selenit, $\mathrm{Na}_{2} \mathrm{SeO}_{3}$ ) veya $1000 \mathrm{mg} / \mathrm{kg}$ oranında selenyum içeren toz formda organik selenyum (selenyum bakımından zenginleştirilmiş maya) katkıları her iki diyette 0.3 $\mathrm{mg} / \mathrm{kg}$ selenyum içerecek şekilde yem miktarı kademeli artırılarak karışım sağlandı ve 6 ayrı deneme diyeti (D1: yağsız diyet, D2: yağsız diyet + inorganik selenyum, D3: yağsız diyet + organik selenyum, D4: yağlı diyet, D5: yağlı diyet + inorganik selenyum, D6: yağlı diyet + organik selenyum) hazırlandı. Denemede kullanılan diyetlerin ham madde ve kimyasal kompozisyonları Tablo 1'de verildi. Deneme diyetinde kullanılan ayçiçek yağının analizle belirlenen yağ asidi kompozisyonu Tablo 2' de verildi. Deneme 12 hafta sürdürüldü. 
Tablo 1. Deneme diyetlerinin ham madde ve kimyasal kompozisyonları (\%).

Table 1. Raw material and chemical compositions of experimental diets (\%).

\begin{tabular}{llllll}
\hline Hammaddeler & Yağsız Diyet & Yağlı Diyet & Kimyasal Kompozisyon & Yağsız Diyet & Yağlı Diyet \\
\hline Mısır & 59 & 42 & Kuru madde* $^{*}$ & 90.31 & 90.53 \\
Buğday & 6 & 14 & Ham protein $^{*}$ & 16.79 & 17.07 \\
Ayçiçek Yağı & - & 3 & ${\text { ME }(k c a l / k g)^{* *}}^{*}$ & 2780 & 2812 \\
Soya Fasulyesi Küspesi & 15 & 15 & Ham kül* $^{*}$ & 11.96 & 12.80 \\
Ayçiçeği Küspesi & 2 & 2 & Ham selüloz $^{*}$ & 3.28 & 4.19 \\
Mısır Gluteni & 6 & 6 & Ham yağ $^{*}$ & 2.69 & 3.69 \\
Buğday Kepeği & 2 & 8 & Nişasta* $^{*}$ & 39.73 & 34.65 \\
Dikalsiyum fosfat & 1.5 & 1.5 & Azotsuz öz madde $^{* *}$ & 55.59 & 52.78 \\
DL- metiyonin & 0.09 & 0.09 & Metiyonin + Sistin $^{* *}$ & 0.67 & 0.67 \\
Kireç Taşı & 7.86 & 7.85 & Lizin $^{* *}$ & 0.70 & 0.72 \\
Tuz & 0.26 & 0.26 & Linoleik asit $^{* *}$ & 1.18 & 2.50 \\
Vitamin karışımı & 0.15 & 0.15 & & & \\
Mineral karışımı & 0.14 & 0.15 & & & \\
Toplam & 100 & 100 & & & \\
\hline
\end{tabular}

Vitamin karışımı 1 kg'ında; vitamin A, 8.000 IU; vitamin D3, 3.000 IU; vitamin E, $25 \mathrm{IU}$; menadione, $1.5 \mathrm{mg}$; vitamin B12, $0.02 \mathrm{mg}$; biotin, $0.1 \mathrm{mg}$; folasin, $1 \mathrm{mg}$; niasin, $50 \mathrm{mg}$; pantotenik asit, $15 \mathrm{mg}$; piridoxine, $4 \mathrm{mg}$; riboflavin, $10 \mathrm{mg}$; tiamin, $3 \mathrm{mg}$ içermektedir. Mineral karışımı 1 kg'ında; manganez $60 \mathrm{mg}$, çinko $25 \mathrm{mg}$, demir $120 \mathrm{mg}$, bakır $5 \mathrm{mg}$, iyot $0.3 \mathrm{mg}$, magnezyum $300 \mathrm{mg}$ içermektedir. *: Analizle bulunmuştur, ${ }^{* *}$ : Hesapla bulunmuștur.

Tablo 2. Deneme diyetinde kullanılan ayçiçek yağının analizle belirlenen yağ asidi kompozisyonu

Table 2. Fatty acid composition of sunflower oil used in the experimental diet determined by analysis

\begin{tabular}{llllll}
\hline Yağ Asitleri & $\%$ & Yağ Asitleri & & $\%$ \\
\hline C4:0 & Butirik asit & - & C18:0 & Srearik asit & 3.99 \\
C6:0 & Kaproik asit & - & C18:1N9C & Oleik asit & 30.01 \\
C8:0 & Kaprilik asit & - & C18:2N6C & Linoleik asit & 57.93 \\
C10:0 & Kaprik asit & - & C20:0 & Arahidik asit & 0.34 \\
C14:0 & Miristik asit & 0.09 & C18:3N6 & V- Linolenik asit & 0.02 \\
C16:0 & Palmitik asit & 5.99 & C20:1N9 & Eikosenoik asit & 0.12 \\
C16:1 & Palmitoleik asit & 0.08 & C18:3N3 & $\alpha$ - Linolenik asit & 0.07 \\
C17:0 & Heptadekanoik asit & 0.04 & C20:2 & Eikosadienoik asit & 0.07 \\
\hline
\end{tabular}

Performans, Yumurta Kalitesi ve Kimyasal Analizler

Yumurta verimi, yumurta ağırlığı, yem tüketimi ve yemden yararlanma oranı gibi performans parametreleri iki haftalık periyotlarda tespit edildi (3). Her tekrardan 4 adet olmak üzere her bir deneme grubundan alınan 28 adet yumurtada yine iki haftalık periyotlarda; şekil indeksi, kabuk kalınlığı, kabuk oranı (4), özgül ağırık (5), Haugh birimi (6), yumurta sarı rengi, ak ve sarı oranı (7), ak ve sarı indeksi (8) gibi yumurta kalite parametreleri belirlendi. Denemede kullanılan diyetlerin besin madde içerikleri AOAC (9)'de belirtilen analiz yöntemlerine göre yapıldı. Diyetlerin metabolik enerji değeri Titus and Fritz (10)'in bildirdiği formüle göre hesaplandı. Yumurta sarısı TBARS değeri tespiti için, deneme sonunda her bir deneme grubunun her alt grubundan 3 adet olmak üzere toplam 21 adet yumurta alındı. $+4^{\circ} \mathrm{C}$ de 0.21 . ve 42 . gün depolanma sürelerini takiben bu 21 yumurtanın her bir depolanma süresinde 7'şer adetinde MDA (malondialdehit) konsantrasyonu analizi Tarladgis ve ark. (11)'nın bildirdikleri yönteme göre yapıldı.

\section{İstatistiksel Analiz}

Bu çalışmada gerekli istatistiksel analizler SAS 9.4 istatistik yazılım programındaki proc GLM alt programı kullanılarak yapıldı. Gruplar arası önemli bulunan farklılıkları belirlemek için Duncan çoklu karşılaştırma testi uygulandı. Elde edilen sonuçların önem düzeyleri $\mathrm{P}<0.05$ 'te değerlendirildi. Çalışmada veri setinin yapısına uygun olarak iki farklı matematiksel model oluşturularak, gerekli istatistiksel analizler yapıldı (12). 
BULGULAR

\section{Performans ve Yumurta Kalitesi}

Yumurtacı tavuk diyetine yağ veya selenyum ilavelerinin, farklı periyotlardaki yumurta verimine etkileri ve interaksiyonları Tablo 3'te, yumurta ağırlığı üzerine etkileri ve interaksiyonları ise Tablo $4^{\prime}$ te verildi. Denem gruplarına ait yem tüketimleri Tablo 5'te, yemden yararlanma oranları da Tablo 6'da gösterildi. Deneme periyotları ortalamasında (0-12. hafta); yumurta verimi, yem tüketimi ve yemden yararlanma oranı bakımından gruplar arasındaki fark istatistiksel olarak önemsiz bulunurken, D6 grubundaki yumurta ağırlığının, D2, D3 ve D5 gruplarına kıyasla daha yüksek $(P<0.05)$ olduğu kaydedildi. Deneme gruplarına ait yumurtaların kalite parametreleri Tablo 7'de verildi. Özgül ağırlık, haugh birimi, ak oranı ve sarı oranı bakımından gruplar arasında istatistiksel fark görülmezken, şekil indeksi, kabuk oranı, kabuk kalınlığı, yumurta sarı rengi, ak ve sarı indeksi değerlendirildiğinde ise gruplar arasındaki fark önemli $(P<0.05)$ bulundu.

Tablo 3. Deneme gruplarına ait yumurta verimleri (\%).

Table 3. Egg productions of the experimental groups (\%).

\begin{tabular}{|c|c|c|c|c|c|c|}
\hline Periyot & D1 & D2 & D3 & D4 & D5 & D6 \\
\hline 0-2.hafta & $97.96 \pm 0.62$ & $95.07 \pm 2.36$ & $95.07 \pm 2.30$ & $96.77 \pm 2.09$ & $95.41 \pm 1.48^{\mathrm{A}}$ & $95.41 \pm 2.24$ \\
\hline 2-4.hafta & $95.75 \pm 1.53$ & $94.05 \pm 2.48$ & $96.60 \pm 1.17$ & $96.94 \pm 2.29$ & $96.60 \pm 1.43^{A}$ & $94.05 \pm 2.17$ \\
\hline 4-6.hafta & $93.71 \pm 2.20$ & $95.17 \pm 2.05$ & $97.96 \pm 0.56$ & $94.90 \pm 2.29$ & $96.60 \pm 0.84^{\mathrm{A}}$ & $94.90 \pm 2.23$ \\
\hline 6-8.hafta & $94.05 \pm 2.01$ & $93.61 \pm 2.29$ & $98.30 \pm 0.44$ & $93.71 \pm 2.61$ & $93.88 \pm 1.83^{\mathrm{AB}}$ & $95.58 \pm 2.36$ \\
\hline 8-10.hafta & $92.86 \pm 1.80$ & $91.94 \pm 2.32$ & $96.09 \pm 1.49$ & $93.30 \pm 2.34$ & $93.88 \pm 1.75^{A B}$ & $92.76 \pm 3.63$ \\
\hline 10-12.hafta & $93.37 \pm 2.32$ & $94.35 \pm 2.14$ & $94.22 \pm 2.66$ & $92.01 \pm 3.37$ & $90.14 \pm 2.41^{B}$ & $93.67 \pm 2.64$ \\
\hline 0-12.hafta & $94.61 \pm 1.38$ & $94.03 \pm 2.07$ & $96.37 \pm 0.80$ & $94.60 \pm 2.41$ & $94.42 \pm 1.14$ & $94.39 \pm 2.47$ \\
\hline$P$ değerleri & & & & & & \\
\hline Y: $\quad 0.409$ & Y×Se: $\quad 0.279$ & \multirow{3}{*}{\multicolumn{5}{|c|}{ Y×SexPer: 0.980}} \\
\hline Se: 0.330 & SexPer: 0.949 & & & & & \\
\hline Per: 0.106 & Y×Per: 0.975 & & & & & \\
\hline
\end{tabular}

A,B: Aynı sütunda, farklı harflerle gösterilen ortalamalar arasındaki farklılıklar önemlidir ( $\mathrm{P}<0.05)$ Y: Yağ, Se: Selenyum, Per: Periyot, D1: yağsı diyet, D2: yağsız diyet + inorganik selenyum, D3: yağsız diyet + organik selenyum, D4: yağlı diyet, D5: yağılı diyet + inorganik selenyum, D6: yağı diyet + organik selenium.

Tablo 4. Deneme gruplarına ait yumurta ağırlıkları (g).

Table 4. Egg weights of the experimental groups (g).

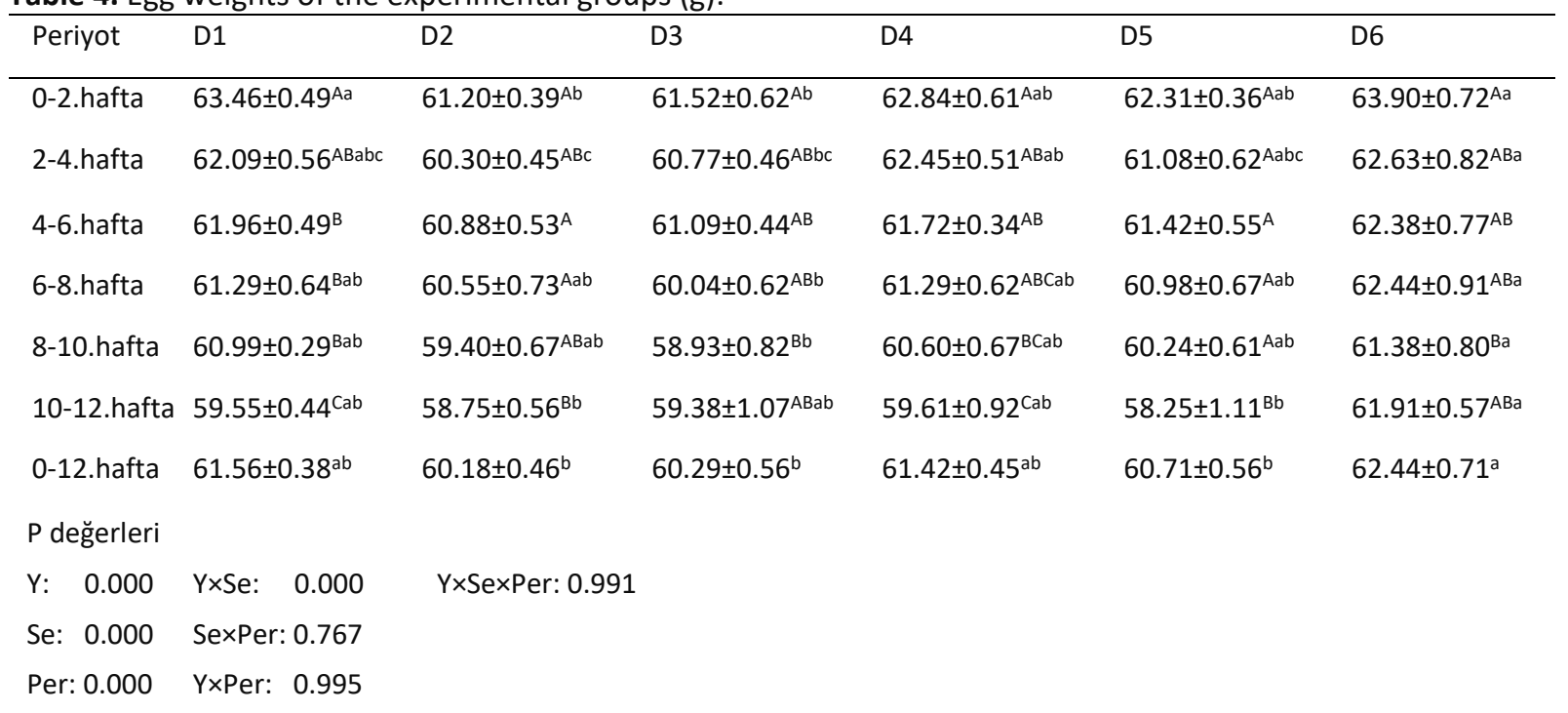

A,B,C: Aynı sütunda, farklı harflerle gösterilen ortalamalar arasındaki farklııklar önemlidir ( $\mathrm{P}<0.05), \mathrm{a}, \mathrm{b}, \mathrm{C}$ : Aynı satırda, farklı harflerle gösterilen ortalamalar arasındaki farklııklar önemlidir $(\mathrm{P}<0.05)$, Y: Yağ, Se: Selenyum, Per: Periyot, D1: yağsız diyet, D2: yağsız diyet + inorganik selenyum, D3: yağsız diyet + organik selenyum, D4: yağlı diyet, D5: yağlı diyet + inorganik selenyum, D6: yağlı diyet + organik selenyum 
Tablo 5. Deneme gruplarına ait yem tüketimleri (g).

Table 5. Feed intakes of the experimental groups (g).

\begin{tabular}{lllllll}
\hline Periyot & D1 & D2 & D3 & D4 & D5 & D6 \\
\hline 0-2.hafta & $90.92 \pm 1.28^{\mathrm{Dbc}}$ & $87.75 \pm 0.72^{\mathrm{Dc}}$ & $87.84 \pm 1.22^{\mathrm{Cc}}$ & $90.92 \pm 1.56^{\mathrm{Cbc}}$ & $95.14 \pm 2.03^{\mathrm{Dab}}$ & $95.65 \pm 1.60^{\mathrm{Ca}}$ \\
2-4.hafta & $110.37 \pm 1.40^{\mathrm{A}}$ & $106.95 \pm 0.80^{\mathrm{B}}$ & $110.00 \pm 0.90^{\mathrm{A}}$ & $109.47 \pm 1.10^{\mathrm{A}}$ & $107.68 \pm 1.34^{\mathrm{B}}$ & $108.93 \pm 1.51^{\mathrm{AB}}$ \\
4-6.hafta & $112.25 \pm 1.06^{\mathrm{Aab}}$ & $111.41 \pm 1.80^{\mathrm{Aab}}$ & $112.29 \pm 1.36^{\mathrm{Aab}}$ & $106.39 \pm 2.80^{\mathrm{Ab}}$ & $113.11 \pm 2.14^{\mathrm{Aa}}$ & $112.07 \pm 1.86^{\mathrm{Aab}}$ \\
6-8.hafta & $109.92 \pm 1.63^{\mathrm{A}}$ & $107.24 \pm 2.03^{\mathrm{B}}$ & $108.70 \pm 1.54^{\mathrm{A}}$ & $108.23 \pm 1.57^{\mathrm{A}}$ & $104.82 \pm 2.03^{\mathrm{B}}$ & $107.95 \pm 1.81^{\mathrm{AB}}$ \\
8-10.hafta & $104.90 \pm 1.75^{\mathrm{B}}$ & $104.22 \pm 1.58^{\mathrm{CB}}$ & $104.43 \pm 1.41^{\mathrm{B}}$ & $105.83 \pm 1.61^{\mathrm{A}}$ & $103.65 \pm 1.71^{\mathrm{BC}}$ & $107.68 \pm 2.05^{\mathrm{AB}}$ \\
10-12.hafta & $100.52 \pm 1.66^{\mathrm{Cab}}$ & $100.20 \pm 1.17^{\mathrm{Cab}}$ & $101.26 \pm 1.48^{\mathrm{Bab}}$ & $97.86 \pm 1.90^{\mathrm{Bb}}$ & $98.81 \pm 1.53^{\mathrm{CDab}}$ & $103.75 \pm 1.80^{\mathrm{Ba}}$ \\
0-12.hafta & $104.81 \pm 1.24$ & $102.97 \pm 1.03$ & $104.09 \pm 1.16$ & $103.12 \pm 1.34$ & $103.87 \pm 1.56$ & $106.01 \pm 1.41$ \\
P değerleri & & & & & & \\
Y: 0.444 & Y×Se: 0.009 & Y×SexPer: 0.570 & & & & \\
Se: 0.023 & SexPer: 0.414 & & & & & \\
Per: 0.000 & Y×Per: 0.006 & & & & &
\end{tabular}

A,B,C,D: Aynı sütunda, farklı harflerle gösterilen ortalamalar arasındaki farklııklar önemlidir ( $\mathrm{P}<0.05)$, a,b,c: Aynı satırda, farklı harflerle gösterilen ortalamalar arasındaki farklııklar önemlidi $(\mathrm{P}<0.05)$, Y: Yağ, Se: Selenyum, Per: Periyot, D1: yağsız diyet, D2: yağsız diyet + inorganik selenyum, D3: yağsız diyet + organik selenyum, D4: yağı diyet, D5: yağı diyet + inorganik selenyum, D6: yağlı diyet + organik selenyum.

Tablo 6. Deneme gruplarına ait yemden yararlanma oranları (g yem/g yumurta).

Table 6. Feed conversion ratios of the experimental groups (g feed/g egg).

\begin{tabular}{lllllll}
\hline Periyot & $\mathrm{D} 1$ & $\mathrm{D} 2$ & $\mathrm{D} 3$ & $\mathrm{D} 4$ & $\mathrm{D} 5$ & $\mathrm{D} 6$ \\
\hline 0-2.hafta & $1.43 \pm 0.02^{\mathrm{Db}}$ & $1.44 \pm 0.02^{\mathrm{Cb}}$ & $1.43 \pm 0.03^{\mathrm{Db}}$ & $1.45 \pm 0.02^{\mathrm{Cb}}$ & $1.53 \pm 0.02^{\mathrm{Ca}}$ & $1.50 \pm 0.01^{\mathrm{Dab}}$ \\
2-4.hafta & $1.78 \pm 0.02^{\mathrm{ABab}}$ & $1.77 \pm 0.02^{\mathrm{ABab}}$ & $1.81 \pm 0.01^{\mathrm{ABa}}$ & $1.75 \pm 0.02^{\mathrm{Aab}}$ & $1.76 \pm 0.02^{\mathrm{Bab}}$ & $1.74 \pm 0.02^{\mathrm{Bb}}$ \\
4-6.hafta & $1.81 \pm 0.02^{\mathrm{Aa}}$ & $1.83 \pm 0.03^{\mathrm{Aa}}$ & $1.84 \pm 0.02^{\mathrm{Aa}}$ & $1.72 \pm 0.04^{\mathrm{Ab}}$ & $1.84 \pm 0.02^{\mathrm{Aa}}$ & $1.80 \pm 0.01^{\mathrm{Aab}}$ \\
6-8.hafta & $1.79 \pm 0.03^{\mathrm{ABab}}$ & $1.77 \pm 0.03^{\mathrm{ABab}}$ & $1.81 \pm 0.02^{\mathrm{ABa}}$ & $1.77 \pm 0.02^{\mathrm{Aab}}$ & $1.72 \pm 0.02^{\mathrm{Bb}}$ & $1.73 \pm 0.03^{\mathrm{Bab}}$ \\
8-10.hafta & $1.72 \pm 0.03^{\mathrm{BC}}$ & $1.76 \pm 0.04^{\mathrm{AB}}$ & $1.77 \pm 0.01^{\mathrm{B}}$ & $1.75 \pm 0.02^{\mathrm{A}}$ & $1.72 \pm 0.02^{\mathrm{B}}$ & $1.75 \pm 0.02^{\mathrm{AB}}$ \\
10-12.hafta & $1.69 \pm 0.03^{\mathrm{C}}$ & $1.71 \pm 0.03^{\mathrm{B}}$ & $1.71 \pm 0.02^{\mathrm{C}}$ & $1.64 \pm 0.03^{\mathrm{B}}$ & $1.70 \pm 0.03^{\mathrm{B}}$ & $1.67 \pm 0.02^{\mathrm{C}}$ \\
0-12.hafta & $1.71 \pm 0.02$ & $1.71 \pm 0.03$ & $1.73 \pm 0.02$ & $1.68 \pm 0.02$ & $1.71 \pm 0.02$ & $1.70 \pm 0.01$
\end{tabular}

$P$ değerleri

Y: $\quad 0.009 \quad Y \times$ Se: $\quad 0.226 \quad$ Y $\times$ SexPer: 0.592

Se: 0.027 SexPer: 0.404

Per: 0.000 Y×Per: 0.003

$\mathrm{A}, \mathrm{B}, \mathrm{C}, \mathrm{D}$ : Aynı sütunda, farklı harflerle gösterilen ortalamalar arasındaki farklılılar önemlidir ( $\mathrm{P}<0.05)$, a,b: Aynı satırda, farklı harflerle gösterilen ortalamalar arasındaki farklılıklar önemlidir $(P<0.05)$, Y: Yağ, Se: Selenyum, Per: Periyot, D1: yağsız diyet, D2: yağsız diyet + inorganik selenyum, D3: yağsız diyet + organik selenyum, D4: yağlı diyet, D5: yağlı diyet + inorganik selenyum D6: yağlı diyet + organik selenyum.

Tablo 7. Deneme gruplarına ait yumurta kalite parametreleri.

Table 7. Egg quality parameters of the experimental groups.

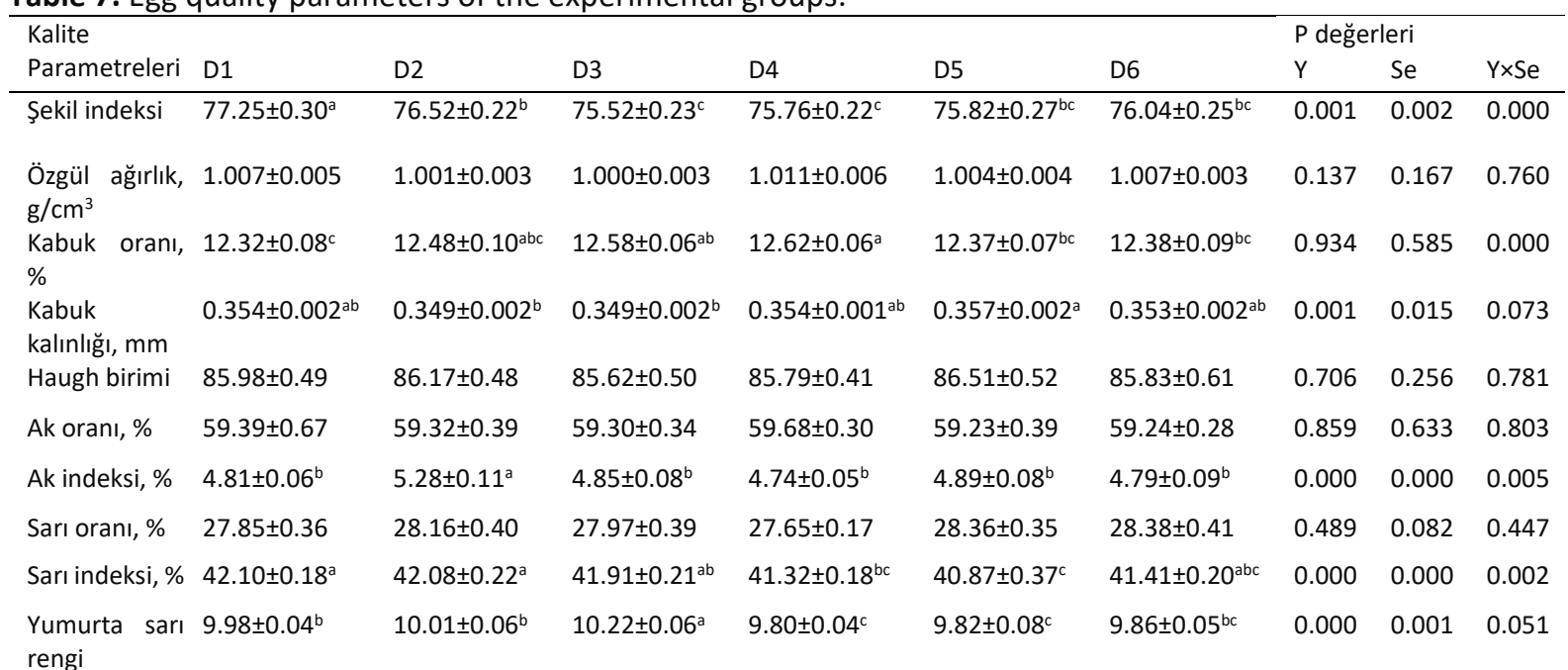




\section{Yumurta Sarısı TBARS Değeri}

Deneme gruplarına ait yumurta sarısı TBARS değerleri Tablo 8'de gösterildi. Depolamanın 0. gününde D4 grubu TBARS değeri, diğer deneme gruplarına kıyasla daha yüksek bulundu $(P<0.05)$. Depolamanın 21. gününde D4 grubunun D3 grubuna göre daha yüksek TBARS değerine sahip olduğu tespit edildi $(\mathrm{P}<0.05)$.

Tablo 8. Deneme gruplarına ait yumurta sarısı TBARS değerleri (mg MDA/kg yumurta).

Table 8. Egg yolk TBARS values of experimental groups (mg MDA/kg egg).

\begin{tabular}{lllllll}
\hline $\begin{array}{l}\text { Depolama } \\
\text { periyodu }\end{array}$ & D1 & D2 & D3 & D4 & D5 & D6 \\
\hline 1 (0.gün) & $0.96 \pm 0.08^{\mathrm{Abc}}$ & $0.95 \pm 0.04^{\mathrm{Abc}}$ & $0.92 \pm 0.04^{\mathrm{Ac}}$ & $1.25 \pm 0.04^{\mathrm{Aa}}$ & $1.01 \pm 0.03^{\mathrm{Bbc}}$ & $1.06 \pm 0.03^{\mathrm{Ab}}$ \\
2 (21.gün) & $1.13 \pm 0.08^{\mathrm{Aab}}$ & $1.04 \pm 0.06^{\mathrm{Aab}}$ & $0.96 \pm 0.05^{\mathrm{Ab}}$ & $1.23 \pm 0.07^{\mathrm{Aa}}$ & $1.15 \pm 0.04^{\mathrm{Aab}}$ & $1.14 \pm 0.05^{\mathrm{Aab}}$ \\
3 (42.gün) & $0.75 \pm 0.02^{\mathrm{Bd}}$ & $0.73 \pm 0.03^{\mathrm{Bd}}$ & $0.79 \pm 0.03^{\mathrm{Bdc}}$ & $0.95 \pm 0.04^{\mathrm{Ba}}$ & $0.87 \pm 0.02^{\mathrm{Cbc}}$ & $0.88 \pm 0.03^{\mathrm{Bab}}$ \\
$1-3(0-42)$ & $0.95 \pm 0.02^{\mathrm{bc}}$ & $0.91 \pm 0.05^{\mathrm{c}}$ & $0.89 \pm 0.03^{\mathrm{c}}$ & $1.14 \pm 0.03^{\mathrm{a}}$ & $1.01 \pm 0.03^{\mathrm{b}}$ & $1.03 \pm 0.03^{\mathrm{b}}$ \\
P değerleri & & & & & \\
Y: 0.000 & Y×Se: 0.079 & Y×SexPer: 0.346 & & \\
Se: 0.000 & SexPer: 0.504 & & & & \\
Per: 0.000 & Y×Per: 0.887 & & & &
\end{tabular}

A,B,C: Aynı sütunda, farklı harflerle gösterilen ortalamalar arasındaki farklılıklar önemlidir ( $\mathrm{P}<0.05), \mathrm{a}, \mathrm{b}, \mathrm{c}, \mathrm{d}$ : Aynı satırda, farklı harflerle gösterilen ortalamalar arasındaki farklılılar önemlidir $(\mathrm{P}<0.05)$, Y: Yağ, Se: Selenyum, Per: Periyot, D1: yağsız diyet, D2: yağsız diyet + inorganik selenyum, D3: yağsız diyet + organik selenyum, D4: yağıl diyet, D5: yağı diyet + inorganik selenyum, D6: yağlı diyet + organik selenyum, TBARS: tiyobarbitürik asit reaktif maddeler, MDA: malondialdehit.

\section{TARTIŞMA ve SONUÇ}

Bu çalışma, yumurtacı tavuk diyetine ayçiçek yağı veya selenyum ilavelerinin; performans, yumurta kalitesi ve yumurta raf ömrüne etkilerinin belirlenmesi amacıyla yapıldı. Deneme periyotları genel ortalamasında; yumurta verimi, yem tüketimi ve yemden yararlanma oranı bakımından gruplar arasında fark görülmedi. Daha önce yapılan çalışmalarda da; yumurtacı tavuk diyetine selenyum $(13,14)$ veya yağ $(15)$ ilavelerinin yumurta verimini etkilemediği bildirilmektedir. Çalışmanın sonuçları ile paralel olarak; Kılınç (1), Lu ve ark. (14) tarafından diyete farklı selenyum kaynağı ilavesinin yem tüketimine etkisinin istatistiksel olarak önemli olmadığı bildirilmektedir. Diyete yağ ilavesinin de yem tüketimini etkilemediğini bildiren Świątkiewicz ve ark. (15)'nın sonuçları mevcut çalışmanın bulgularını desteklemektedir. Yumurtacı tavuk diyetine yağ (15) veya selenyum (14) ilavelerinin yemden yararlanma oranına etkilerinin istatistiksel olarak önemli olmadığını bildiren çalışmaların aksine
Çelebi (16) yaptığı çalışmada; diyete ayçiçek yağı ilavesinin yemden yaralanma oranını düşürdüğünü, Kılınç (1) ise; organik Se ilave edilen diyetle beslenen grupta inorganik Se ilave edilen diyetle beslenen gruba kıyasla daha düşük olduğunu bildirmektedir. D6 grubu yumurta ağırlığının, D2, D3 ve D5 gruplarına kıyasla daha yüksek olduğu tespit edilmiş olup, D3 grubu ile D6 grubu arasındaki farklılığın yağdan kaynaklandığı ve buna bağlı olarak yağ ilavesinin yumurta ağırlığını artırdığı düşünülmektedir. Eseceli (17) yaptığı çalışmada; en yüksek yumurta ağırlığının ayçiçek yağı ile birlikte $C$ vitamini katkısı yapılan grupta elde edildiğini bildirmektedir. Diyete ilave edilen yağların özellikle kolay emilebilen doymamış yağ asitlerince zengin olması ve bu yağ asitlerinin yumurta sarısının yapısına dahil olmasından dolayı,yumurta ağırığının arttığı bildirilmektedir (18). Deneme gruplarına ait yumurtalarda tespit edilen kalite parametrelerinden; özgül ağırlık, haugh birimi, ak oranı ve sarı oranı bakımından, 0-12. hafta genel ortalama değerlerinde gruplar arasındaki fark 
istatistiksel olarak önemsiz bulundu. Yumurtacı tavuk diyetlerine farklı bitkisel yağ ilavelerinin (19) veya selenyum katkılarının (20) Haugh birimi üzerine etkisinin önemli olmadığını bildiren çalışmalar sunulan sonuçları desteklemektedir. Marion ve ark. (21) ile Cavers (22) yaptıkları çalışmalarda; ak ve sarı oranı üzerine diyet farklılıklarının etkisinden daha çok; tavuğun ırk, yaş, yumurta büyüklüğü ve verim döneminin etkili olduğunu bildirmektedirler. Sunulan çalışmada anılan parametrelerde katkı maddelerinin önemli bir etkisinin olmamasının bu faktörlere bağlı olabileceği düşünülmektedir. Yumurta şekil indeksi; bütün gruplarda genel olarak benzer bulunurken, D1 grubunda diğer deneme gruplarına kıyasla daha yüksek belirlendi. Çelebi (16) ise yaptığı çalışmada; yumurta tavuğu diyetlerine farklı yağ ilavelerinin şekil indeksi üzerine etkilerinin önemsiz olduğunu bildirmektedir. Kabuk oranı D4 grubunda D1, D5 ve D6 gruplarına kıyasla daha yüksek belirlendi. Yapılan bir çalışmada (23) yumurta ağırlığının kabuk oranını etkilediği bildirildiğinden, sunulan çalışmada da yumurta ağırlığındaki farklılıktan dolayı yumurta kabuk oranının değiştiği düşünülmektedir. Yumurta kabuk kalınlığı bakımından, D5 grubuna ait değerler, D2 ve D3 gruplarına kıyasla daha yüksek bulundu. Diyete yağ ilavesinin kabuk kalınlığı üzerine etkilerinin önemli olduğu belirlenmiş olup, Batkowska ve ark. (19) yaptığı çalışmadan elde ettiği veriler de bu sonuçları desteklemektedir. Yumurta sarı renginin D3 grubunda, diğer gruplara kıyasla daha yüksek olduğu belirlendi. Yağsız gruplar ile yağlı gruplar arasındaki farkın diyete yağ ilavesinden kaynaklandığı düşünülmektedir. Nitekim rafine yağlarda daha az ksantofil bulunabileceğini bildiren çalışmalardan $(24,25)$ yola çıkarak; yağı diyette enerji dengesini sağlamak amacıyla diyetten çıkarılan bir miktar mısır ve ilave edilen ayçiçek yağından dolayı eksilen ksantofil miktarına bağlı olarak, yağlı diyetlerde yumurta sarı renginin düşmüş olabileceği düşünülmektedir. D2 grubuna ait ak indeksi değeri, diğer gruplara kıyasla daha yüksek tespit edildi. Yumurtacı tavuk diyetlerine farklı katkıların yumurta ak indeksine etkilerinin önemli olmadığını bildiren çalışmalar $(26,27)$ mevcuttur. Sarı indeksi bakımından; D1 ile D4 arasında, D2 ile D5 arasında ortaya çıkan farkın yağdan kaynaklanmış olabileceği düşünülmektedir. Elde edilen sonuçların aksine; Reshadi ve ark. (28) yumurtacı tavuk diyetine oregon yağı ve selenyum ilavelerinin yumurta sarı indeksine etkilerinin önemli olmadığını bildirmekle birlikte, başka bir araştırmada yumurta kalitesinin; genotip, yaş, canlı ağırlık, yetiştirme sistemleri, sağlık, beslenme, stres ve barınma gibi faktörlerden etkilendiği de bildirilmektedir (29). Gruplara ait yumurtaların depolama periyotları ortalamasında; TBARS değeri, D4 grubunda diğer gruplara kıyasla daha yüksek tespit edildi. Yağsız diyetle beslenen gruplar ile yağlı diyetle beslenen gruplar arasındaki farklııkların diyete yağ ilavesinden kaynaklandığı ve buna bağlı olarak da yağ ilavesinin yumurta TBARS değerini artırdığı belirlendi. Kralik ve ark. (30)'nın yapmış olduğu çalışma bu sonucu destekler niteliktedir. Yumurta sarısında bulunan çoklu doymamış yağ asitlerinin depolama sırasında oksidasyona daha duyarlı oldukları bildirilmektedir (31). Buna göre; denemede kullanılan ayçiçek yağının çoklu doymamış yağ asitleri bakımından (özellikle linoleik asit) zengin olması ve bu yağ asitlerinin de yumurta sarısı yağ asidi profiline yansımış olabileceğine bağlı olarak, diyete yağ ilavesinin yumurta sarısı TBARS değerini artırdığı, dolayısıyla yumurta raf ömrünü olumsuz etkilediği sonucuna varıldı. Yağlı diyetle beslenen gruplar arasındaki farklılık önemli olarak belirlenirken, bu farklılığın diyete selenyum ilavesinden kaynaklandığı ve bundan dolayı selenyum ilavesinin yumurta sarısı TBARS değerini azalttığı belirlendi. Laika ve Jahanian (32), yumurta tavuğu diyetine farklı yağ ilaveleri ile organik selenyum katkısı kullandıkları çalışmada elde ettiği veriler ile bu sonucu desteklemektedir. 
Selenyumun antioksidan bir mineral madde olması ve bu özelliğinden dolayı oksidayonu azaltmasına bağlı olarak yumurta sarısı TBARS değerini düşürmüş olabileceği sonucuna varıldı. Muhammad ve ark. (33)'nın yapmış olduğu çalışma bu sonucu desteklemektedir. Depolama periyotları incelendiğinde, bütün gruplarda 1. ve 2. depolama periyotlarındaki TBARS değerinin 3. depolama periyoduna kıyasla daha yüksek olduğu bulundu. 3 . depolama periyodunda TBARS değerinin azaldığı tespit edilirken, bu azalmanın bazı araştırıcılar tarafından bildirildiği üzere, MDA'nın çok çeşitli bileşiklerle (aminler, aminoasitler, aminoşekerler, proteinler, nükleositler) reaksiyonu ve dimer veya trimer şeklinde polimerizasyonuna bağlı olarak meydana gelmiş olabileceği düşünülmektedir $(34,35)$. Bu reaksiyonların, tiyobarbitürik asit ile reaksiyona girebilecek MDA miktarını azalttığı ve buna bağlı olarak TBARS değerini düşürdüğü bildirilmektedir (36).

Sonuç olarak; yumurta tavuğu diyetine ayçiçek yağı veya selenyum ilavelerinin genel olarak performans ve yumurta kalite parametrelerini etkilemediği, ayçiçek yağı ilavesinin yumurta sarısı TBARS değerini artırdığı, selenyum ilavesinin ise bu artışı engelleyerek, yumurta raf ömrü üzerine pozitif etkileri olduğu belirlendi.

\section{Teşekkür}

Bu araştırma, Van Yüzüncü Yıl Üniversitesi, Bilimsel Araştırma Projeleri Koordinasyon Birimi tarafından TDK-2016-5089 nolu proje ile desteklenmiştir.

\section{Çıkar Çatışması}

Yazarlar, çıkar çatışması olmadığını beyan eder.

\section{KAYNAKLAR}

1. Kılınç ÖO., 2013. Illave organik ve inorganik selenyum preparatlarının ve ilave vitamin E’nin yumurta tavuklarında verim ve bazı kan parametrelerine, yumurta selenyum içeriğine ve plazma glutatyon peroksidaz enzim aktivitesine etkisinin belirlenmesi. Selçuk Üniversitesi, Fen Bilimleri Enstitüsü, Türkiye.

2. Tabar B., Baştürk A., 2018. Farklı bitkisel ekstraktların ayçiçeği yağının oksidatif stabilitesi üzerine etkileri. J Food, 43, 333-346.

3. Torki M., Mohebbifar A., Mohammadi H., 2021. Effects of supplementing hen diet with Lavandula angustifolia and/or Mentha spicata essential oils on production performance, egg quality and blood variables of laying hens. Vet Med Sci, 7, 184-193.

4. Yörük MA., Bolat D., 2003. Mısır ve arpaya dayalı yumurta tavuğu rasyonlarına farklı enzim katkılarının çeşitli verim özelliklerine etkisi. Turk J Vet Anim Sci, 27, 789-796.

5. Harms RH., Rossi AF., Sloan DR., Miles RD., Christmas RB., 1990. A method for estimating shell weight and correcting specific gravity forr egg weight in eggsheel quality studies. Poult Sci, 69, 48-52.

6. Haugh RR., 1937. The haugh ünit for measuring egg quality. US Egg Poultry Magazine, 43, 522555.

7. Aydın A., Bölükbaşı ŞC., 2020. Effect of supplementation of Hen Diet with pennyroyal extract (Mentha pulegium) on performance, egg quality and yolk TBARS values. Pakistan J Zool, 52, 1045-1051.

8. Card LE., Nesheim MC., 1972. Poultry Production. 11th ed., Lea and Febiger Press, Phidelphia.

9. Association of Official Analytical Chemists, 1995. Official Methods of Analysis of AOAC International, 16th ed., Arlington.

10. Titus HW., Fritz JC., 1971. Percentage multipliers for computing metabolizable energy values, for chickens, of some feedstuffs used in the feding of poultry. In "The Scientific Feeding of Chickens", 5th ed., 295-298, Interstate, Danville, IL.

11. Tarladgis BM., Watts MT., Younathan LR., Dugan A., 1960. Distillation method for the quantitative 
determination of malonaldehyde in rancid foods. J Am Oil Chem Soc, 37, 44-48.

12. SAS, 2015. SAS/Stat Software Hangen and Enhanced, SAS Institute Incorporation, USA.

13. Lu J., Qu L., Shen MM., Wang XG., Guo J., Hu YP., Dou TC., Wang KH., 2019. Effects of high-dose selenium-enriched yeast on laying performance, egg quality, clinical blood parameters, organ development, and selenium deposition in laying hens. Poult Sci, 98, 2522-2530.

14. Lu J., Qu L., Ma M., Li F., Wang XG., Yang Z., Wang KH., 2020. Efficacy evaluation of seleniumenriched yeast in laying hens: effects on performance, egg quality, organ development, and selenium deposition. Poult Sci, 99, 62676277.

15. Swiatkiewicz S., Arczewska-Wlosek A., Szczurek W., Calik J., Bederska-Lojewska D., OrczewskaDudek S., Muszynski S., Tomaszewska E., Jozefiak D., 2020. Algal oil as source of polyunsaturated fatty acids in laying hens nutrition: Effect on egg performance, egg quality indices and fatty acid composition of egg yolk lipids. Ann Anim Sci, 20, 961-973.

16. Çelebi Ş., 2003. Yumurta tavuğu rasyonlarına geç dönemde hayvansal ve bitkisel yağ ilavesinin performans, yumurta kalitesi ve yumurta sarısı yağ asidi kompozisyonu üzerine etkileri. Atatürk Üniversitesi, Fen Bilimleri Enstitüsü, Türkiye.

17. Eseceli H., 2003. Farklı yağ asidi kaynağı içeren yumurta tavuğu rasyonlarına $E$ ve $C$ vitaminleri ilavesinin yumurta sarısı yağ asidi kompozisyonuna, lipid peroksidasyon düzeyine ve performansa etkisi. İstanbul Üniversitesi, Sağlık Bilimleri Enstitüsü, Türkiye.

18. Şenköylü N., 2001. Yemlik Yağlar. ISBN 97593691-1-7, 164, NRA, Tekirdağ.

19. Batkowskaa J., Drabika K., Brodackia A., Czechb A., Adamczuk A., 2021. Fatty acids profile, cholesterol level and quality of table eggs from hens fed with the addition of linseed and soybean oil. Food Chem, 334, 127612.

20. Liu H., Yu O., Tang X., Fang C., Chen S., Fang R.,
2020. Effect of Selenium on Performance, Egg Quality, Egg Selenium Content and Serum Antioxidant Capacity in Laying Hens. Pakistan J Zool, 52, 635-640.

21. Marion WW., Nordskog AW., Tolman HS., Forsythe RH., 1964. Egg Composition as Influenced by Breeding, Egg Size, Age and Season. Poult Sci, 43, 255-264.

22. Cavers JR., 1970. EGGS, the production, identification and retention of quality in eggs. Department of Poult Sci. Ontario Agricultural College, University of Guelph.

23. Ürüşan H., Bölükbaşı ŞC., 2020. Yumurta kalitesini iyileştirici güncel besleme çalışmaları. DÜFED, 9, 65-78.

24. Pardıo V., Landın L., Walıszewskı K., Avalos M., Flores A., Guzman L., 1992. Effect of soybean soapstock on Laying Hen performance and egg quality parameters. Poult Sci, 9480-9481.

25. Mızrak C., Ceylan N., Çiftçi i.., Kahraman Z., Karaçaltı MS., 2005. Ayçiçek yağı yerine ayçiçeği asit yağı kullanılmasının yumurta tavuklarında performans, yumurta kalitesi ve yağ asitleri kompozisyonu üzerine etkileri. Tavukçuluk Araş Derg, 6, 21-24.

26. Kaya A., Kaya H., Macit M., Çelebi Ş., Esenbuğa N., Yörük MA., Karaoglu M., 2013. Effects of dietary inclusion of plant extract mixture and copper into layer diets on egg yield and quality, yolk cholesterol and fatty acid composition. Kafkas Univ Vet Fak Derg, 19, 673-679.

27. Çiftçi ME., 2015. Yumurtacı tavuk rasyonlarına kişniş yağı (coriander oil) ilavesinin performans, yumurta kalite özellikleri, yumurta sarısı tbars değerleri ve bazı kan parametreleri üzerine etkisi. Atatürk Üniversitesi, Fen Bilimleri Enstitüsü, Türkiye.

28. Reshadi H., Torki M., Mohammadi H., 2020. Changes in performance, egg quality and blood parameters of laying hens fed selenium and oregano oil. Anim Prod Sci, 60, 1620-1629.

29. Lordelo M., Cid J., Cordovil CM., Alves SP., Bessa RJ., Carolino I., 2020. A comparison between the 
quality of eggs from indigenous chicken breeds and that from commercial layers. Poult Sci, 99, 1768-1776.

30. Kralik G., Grcevic M., Hanzek D., Margeta P., Galovic O., Kralik Z., 2020. Feeding to produce $n$ 3 fatty acid-enriched table eggs. J Poult Sci, 57, 138-147.

31. Matumoto-Pintro PT., Murakami AE., Vital ACP., Croge C., da Silva DF., Ospina-Roja IC., BGuerra AFQG., 2017. Effects of storage time and temperature on lipid oxidation of egg powders enriched with natural antioxidants. Food Chem, 228, 463-468.

32. Laika M., Jahanian R., 2015. Dietary supplementation of organic selenium could improve performance, antibody response, and yolk oxidative stability in laying hens fed on diets containing oxidized fat. Biol Trace Elem Res, 165, 195-205.
33. Muhammad Al., Mohamed DAA., Chwen LT., Akit H., Samsudin AA., 2021. Effect of sodium selenite, selenium yeast, and bacterial enriched protein on chicken egg yolk color, antioxidant profiles, and oxidative stability. Foods, 10, 871.

34. Esterbauer H., Schaur RJ., Zollner H., 1991. Chemistry and biochemistry of 4hydroxynonenal, malonaldehyde and related aldehydes. Free Radical Biol Med, 11, 81-128.

35. Aubourg SP., 1993. Review: Interaction of malondialdehyde with biological molecules-New trends about reactivity and significance. Int $\mathrm{J}$ Food Sci Technol, 28, 323-335.

36. Galobart J., Barroeta AC., Baucells MD., Cortinas L., Guardiola F., 2001. $\alpha$-Tocopherol transfer efficiency and lipid oxidation in fresh and spraydried eggs enriched with $\omega 3$ - polyunsaturated fatty acids. Poult Sci, 80, 1496-1505. 